\title{
Morpho-anatomical studies on the leaf reduction in Casuarina: the ecology of xeromorphy
}

\author{
Veit M. Dörken ${ }^{1}$ Robert F. Parsons ${ }^{2}$
}

\begin{abstract}
Key message The foliage characters found in Casuarina seedlings may represent the ancestral, scleromorphic ones found in the Casuarinaceae. In the adults studied, these are replaced by derived xeromorphic features.

Abstract The ontogenetic changes in the foliage of two Casuarina species were investigated. While the cotyledons are flattened linear structures, all other leaf-types are strongly reduced. Except for the two primary leaves, all subsequent leaves are strongly fused to each other and also to the shoot axis, except for the leaf tips; the shoot axis is completely surrounded by photosynthetic leaf tissue and the branchlet is not made up of cladodes but of extended leaf sheaths which are a novel strategy for achieving reduced photosynthetic area. In seedlings there are four leaves per node, forming four shallow vertical furrows where light-exposed and non-encrypted stomata are developed. These features are also developed in the adult foliage within the strictly scleromorphic genus Gymnostoma, clearly the most mesic of the present day genera of Casuarinaceae and very likely to include the ancestral types. Thus, we assume that the Casuarina-seedling leaves reflect the ancestral scleromorphic condition. In the adult foliage,
\end{abstract}

Communicated by L. Gratani.

Veit M. Dörken

veit.doerken@uni-konstanz.de

Robert F. Parsons

r.parsons@latrobe.edu.au

1 Department of Biology, University of Konstanz, M 613, Universitätsstr. 10, 78457 Constance, Germany

2 Department of Ecology, Environment and Evolution, La Trobe University, Bundoora, Melbourne, VIC 3086, Australia the number of leaves per node is strongly increased, which leads to the formation of several nearly closed vertical furrows on the shoot, where stomata are shaded and strongly encrypted. Thus, the adult foliage shows several xeromorphic features that are absent in the juvenile foliage. Our morpho-anatomical data mapped on ecological and palaeobotanical data show that within Casuarinaceae the foliage shifted from scleromorphic to xeromorphic. Thus, the adult xeromorphic foliage in Casuarina is the derived, advanced state.

Keywords Anatomy $\cdot$ Casuarina $\cdot$ Leaf $\cdot$ Morphology . Scleromorphy $\cdot$ Xeromorphy

\section{Introduction}

This is one of a series of papers dealing with the anatomy, morphology, evolution and ecology of extreme leaf reduction in seed plants, with special emphasis on documenting any changes in the leaf form from seedlings to adults (e.g. Dörken 2013; Dörken and Parsons 2016).

Strong leaf reduction is quite common in gymnosperms (e.g. Farjon 2005, 2010a, b; Eckenwalder 2009; Dörken 2013; Dörken and Parsons 2016), but it can also be found in a wide range of angiosperms (e.g. Rehder 1967; Krüssmann 1976, 1977, 1978; Kubitzki et al. 1993; Kubitzki 2004) and can also be proven for extinct taxa in the fossil record (e.g. Foster and Gifford 1974; Taylor et al. 2009). In evergreen taxa it is often associated with xeric conditions, where it reduces transpiration via the lamina for plants in habitats where water is the main limiting factor (e.g. Thoday 1931; Blum and Arkin 1984; Blum 1996; Bosabalidis and Kofidis 2002; Parsons 2010; Seidling et al. 2012). However, xeric conditions 
especially drought are just some of the forces leading to leaf reduction. In other habitats, e.g. subalpine and alpine ones, leaf reduction can be correlated with stress from both low temperatures and water deficit (e.g. Korner 2003; Parsons 2010). Also, low soil fertility, especially low phosphorus availability, can lead to the formation of strongly reduced leaves (e.g. Loveless 1961, 1962; Beadle 1966; Seddon 1974; Hill and Merrifield 1993; Hill 1998; Salleo and Nardini 2000; Dörken and Parsons 2016) as is typical for several Ericaceae (e.g. Düll and Kutzelnigg 2011; Dörken and Jagel 2014). At first glance, both drought and a lack of nutrients seem to lead to the same leaf structures. However, drought leads to a xeromorphic leaf structure showing, e.g. a thick cuticle, encrypted stomata or dense pubescence, while low soil fertility leads to a scleromorphic one with, e.g. high amounts of sclerenchyma (Dörken and Parsons 2016). In this paper, we strictly follow Hill (1998) using the term xeromorphy to refer to morpho-anatomical responses to water deficit and scleromorphy to nutrient deficient soils especially to low levels of phosphorus. Of course some features like strong leaf reduction can be found in xeromorphic and scleromorphic foliage as well.

In this paper, we turn our attention to the eudicot family Casuarinaceae (Fagales), a small subtropical to temperate group of trees and shrub with four genera, Gymnostoma, Allocasuarina, Casuarina and Ceuthostoma (Torrey and Berg 1988; Kubitzki et al. 1993; Steane et al. 2003). All Casuarinaceae are characterized by an evergreen habit and a strong leaf reduction. The family is unusually interesting because its affinities are obscure (Hill and Brodribb 2001); members are easily distinguished from all other angiosperms because of their needle-like articulate branchlets with longitudinal ridges (phyllichnia) separated by furrows and other features (Zamaloa et al. 2006). Due to these unique foliar features we have chosen to work on this family partly because ontogenetic studies about its leaf development do not exist and the exact interpretation of stem and leaf tissue is still open. More importantly, we had access to seed and seedlings of Casuarina and were able to compare our data with those of Torrey and Berg (1988) on Gymnostoma. This is important because Gymnostoma contrasts with Casuarina by having the oldest fossils in the family including species with non-xeromorphic characters (Steane et al. 2003). Thus, our aims are to explore the evolution of scleromorphy and xeromorphy by documenting the ontogenetic changes in leaf characters with seedling age in species of Casuarina and to compare these data with published data from Gymnostoma. Also, we make a detailed examination of the extent of leaf and stem tissue in Casuarina branchlets to establish what constitutes leaf reduction in that genus.

\section{Materials and methods}

\section{Material}

Seeds of Casuarina cunninghamiana Miq. were obtained from the Murray Mallee Seedbank, Nyah, Victoria, Australia, and seeds of the ecologically contrasting Casuarina equisetifolia L. from the Botanic Garden Konstanz, Germany. They were germinated and grown in a temperate glass house with long day conditions in the Botanic Garden Konstanz. Seeds were sown in a mixture of compost and vermiculite (5:1). The glasshouse temperature ranged from $25^{\circ} \mathrm{C}$ (day) to $15^{\circ} \mathrm{C}$ (night). Material from adult individuals was received from the Botanic Garden of the Ruhr-University Bochum (Germany) where the trees are cultivated in a temperate house. Voucher specimens of the investigated taxa are lodged at the FRP-Herbarium of the Palmengarten Frankfurt a. M. (Germany).

\section{Methods}

Freshly collected material was photographed and then fixed in FAA $(100 \mathrm{ml} \mathrm{FAA}=90 \mathrm{ml} 70 \%$ ethanol $+5 \mathrm{ml}$ acetic acid $96 \%+5 \mathrm{ml}$ formaldehyde solution $37 \%$ ) before being stored in $70 \%$ ethanol. The leaf anatomy was studied from serial sections using the classical paraffin technique and subsequent astrablue/safranin staining (Gerlach 1984). Macrophotography was accomplished using a digital camera (Canon PowerShot IS2) and microphotography with a digital microscope (Keyence VHX 500F) equipped with a high-precision $\mathrm{VH}$ mounting stand with $\mathrm{X}-\mathrm{Y}$ stage and bright-field illumination (Keyence VH-S5).

\section{Results}

\section{Leaf morphology and leaf anatomy of $C$. cunninghamiana}

\section{Cotyledons}

The hypocotyl is well developed (Fig. 1a). The two small, flattened, bifacial cotyledons are 2.5-4-mm long and 2.0-2.5-mm wide (Fig. 1b). They are amphistomatic and apparently more frequent on the adaxial side. They are irregularly arranged and slightly sunken in the epidermis. The epidermal cells of both sides are similar in size and shape. Those on the leaf margin are up to double the size of the others. The epidermis is covered with a thin cuticle. The mesophyll is distinctly dimorphic. A well-developed palisade parenchyma is orientated towards the light exposed adaxial side of the leaf and consists of 2-3 cell layers. The spongy parenchyma consists of isodiametric cells showing 

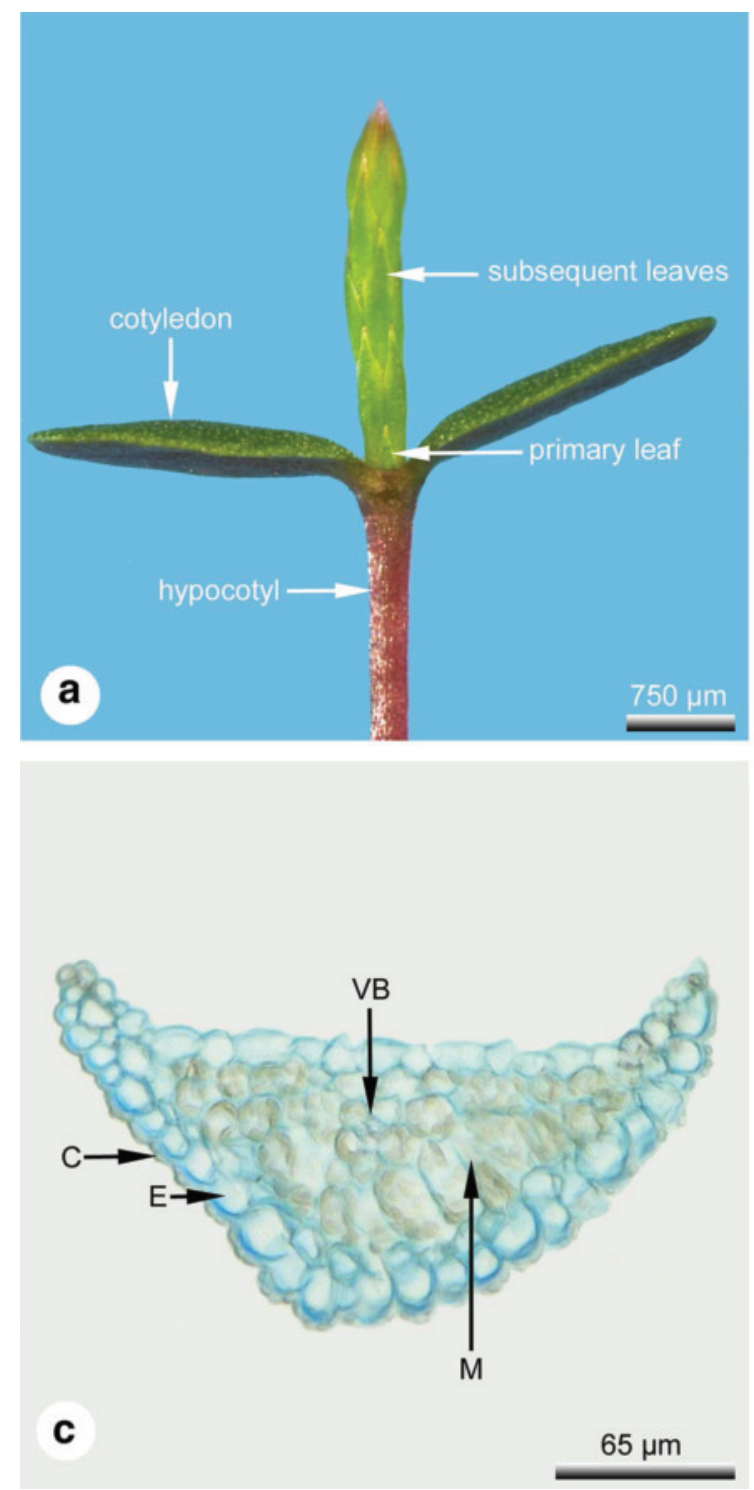

Fig. 1 Casuarina cunninghamiana, leaf development in different ontogenetic stages I: juvenile leaves; a seedling; b cotyledon (cross section); c primary leaf (cross section); d young subsequent leaves at a shoot axis (cross axis), $C$ cuticle, $C L$ chlorenchyma, $C O$ col-

large intercellular spaces. The cotyledons are supplied with a single collateral vascular bundle strand that branches several times. There is no distinct bundle sheath (Fig. 1b).

\section{Primary leaves}

The epicotyl is strongly reduced (Fig. 1a). The two primary leaves are small, 0.4-0.6- $\mathrm{mm}$ long and 0.1-0.2-mm wide (Fig. 1c). The adaxial side is orientated towards the shoot axis and becomes the shaded surface, the former abaxial side the new light-exposed surface. The leaves are amphistomatic, but with stomata mostly arranged on
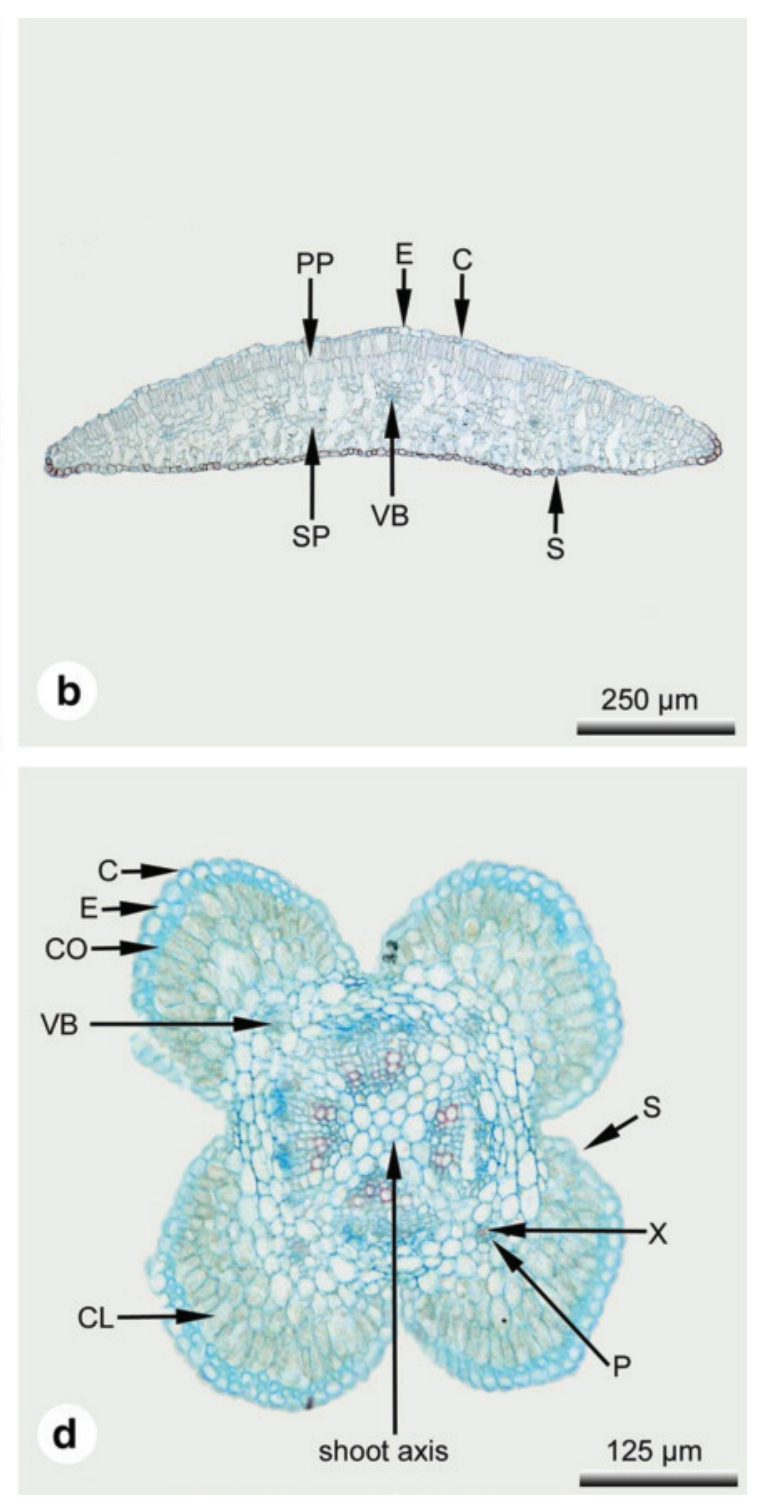

lenchyma, $E$ epidermis, $M$ mesophyll, $P P$ palisade parenchyma, $P$ phloem, $S$ stoma, $S P$ spongy parenchyma, $V B$ vascular bundle, $X$ xylem

the adaxial side. They are slightly sunken in the epidermis. The epidermal cells of the light-exposed abaxial side are about double the size of those of the shaded adaxial side (Fig. 1c). Also, the cell walls of the lightexposed epidermal cells are two to three times thicker than the cell walls of shaded epidermal cells. A weakly developed cuticle is present. The mesophyll is monomorphic and consists of several isodiametric cells showing weakly developed intercellular spaces. There is only a single, weakly developed, unbranched collateral vascular bundle strand. There is no distinct bundle sheath (Fig. 1c). 
There are four leaves at each node. They are about 4-10$\mathrm{mm}$ long and 0.2-0.4-mm wide (Fig. 1a). The adaxial surface of subsequent juvenile leaves is orientated towards the shoot axis. The leaves are strongly fused to each other and to the cortical tissue of the complete internode (Fig. 1a). At the subsequent node, the leaves are still fused to each other but no longer to the shoot axis. In the most distal part only the tips are free. Thus the node is surrounded by a closed leaf sheath (Fig. 1a). There is no sharp boundary layer between leaf- and shoot-tissue (Fig. 1d). The stomata which develop are light-exposed and non-encrypted in the four shallow vertical furrows. There are no trichomes covering the stomata; a thin cuticle covers the epidermis. Below the epidermis, a collenchyma consisting of 1-2 layers of small cells with strongly thickened walls occurs, below which is a chlorenchyma consisting of palisade parenchymalike cells. There is a single unbranched collateral vascular bundle strand supplying the leaf. There is no distinct bundle sheath (Fig. 1d).

\section{Adult leaves}

On adult individuals, 6-10 (-11) whorled leaves are inserted per node. These are about 6-15-mm long and 0.2-0.3-mm wide and show a hyaline tip (Fig. 2a). Later the leaf tips become withered and brown. The leaves are strongly fused to each other and also to the cortical tissue for the length of the internode (Figs. 2c, d, 3). Only the leaf tips are free (Figs. 2a, 3a). At the subsequent node, the leaves are still fused to each other but no longer to the shoot axis and surround the node as a closed leaf sheath (Fig. 3). Between leaf- and shoottissue no sharp boundary layer is developed (Figs. 2c, d, 3). A weakly developed cuticle is present. Stomata are deeply sunken in the epidermis and only become encrypted in the shaded vertical, nearly closed furrows between the leaves. On the light-exposed surface of the leaves, stomata are absent. Below the epidermis, a collenchyma consisting of 1-2 layers of cells with strongly thickened walls is formed. In the region of the midvein, the collenchyma consists of 4-6 cell layers. The collenchyma cells are about half the size of the epidermal cells. Below the collenchyma, a well-developed palisade parenchyma-like chlorenchyma develops. The leaf is supplied with a single unbranched collateral vascular bundle strand, which ends blindly in distal parts of the leaf shortly below the tip. There is no bundle sheath (Fig. 2b).

\section{Cotyledons}

The hypocotyl is well developed (Fig. 4a). The two cotyledons are flattened, bifacial structures, 2.2-2.9-mm long and 0.9-1.2-mm wide (Fig. 4b). They are amphistomatic, with the majority of stomata developed irregularly on the adaxial side. The stomata are slightly sunken in the epidermis. The epidermal cells of both leaf sides are similar in size and shape. The mesophyll is dimorphic, with a distinct palisade parenchyma located towards the light-exposed adaxial side and a spongy parenchyma with huge intercellular spaces towards the shaded abaxial side. The leaf is supplied with a single collateral vascular bundle strand that branches several times. There is no distinct bundle sheath (Fig. 4b).

\section{Primary leaves}

The epicotyl is strongly reduced (Fig. 4a). The two primary leaves are about $0.4-0.6-\mathrm{mm}$ long and $0.1-0.2-\mathrm{mm}$ wide (Fig. 4c). They are strongly adpressed to the shoot axis, so that the abaxial side is light-exposed and the adaxial side shaded (Fig. 4a). The primary leaves are amphistomatic, but with stomata mostly arranged on the adaxial side. They are slightly sunken in the epidermis. The epidermal cells of the abaxial surface are about double the size of those of the adaxial side. The cell walls of the shaded epidermal cells are about half or a third of the thickness of those of the light-exposed epidermal cells. The mesophyll is monomorphic and consists of isodiametric cells showing small intercellular spaces. A weakly developed, unbranched collateral vascular bundle is developed. There is no distinct bundle sheath (Fig. 4c).

\section{Subsequent juvenile leaves}

In young seedlings, four whorled subsequent leaves are inserted per node (Fig. 4a). They are 5-10-mm long and 0.2-0.4-mm wide (Fig. 4d) and are strongly reduced and fused to each other and to the cortical tissue of the shoot axis over the complete internode (Fig. 4d). Only the leaf tips are free (Fig. 4a). At the subsequent node, the leaves are still fused to each other but no longer to the shoot axis. Thus the node is surrounded by a closed leaf sheath (Fig. 4a). No sharp boundary layer between leaf- and shoot-tissue is developed (Fig. 4d). The stomata which develop are nonencrypted and more or less light-exposed in the four vertical shallow furrows. Trichomes covering the stomata are absent. Below the epidermis, a weakly developed collenchyma can be detected, consisting of one interrupted layer of cells with strongly thickened cell walls. These cells are about half the size of the epidermal cells. Below the collenchyma, a palisade parenchyma-like chlorenchyma is developed. The leaf 

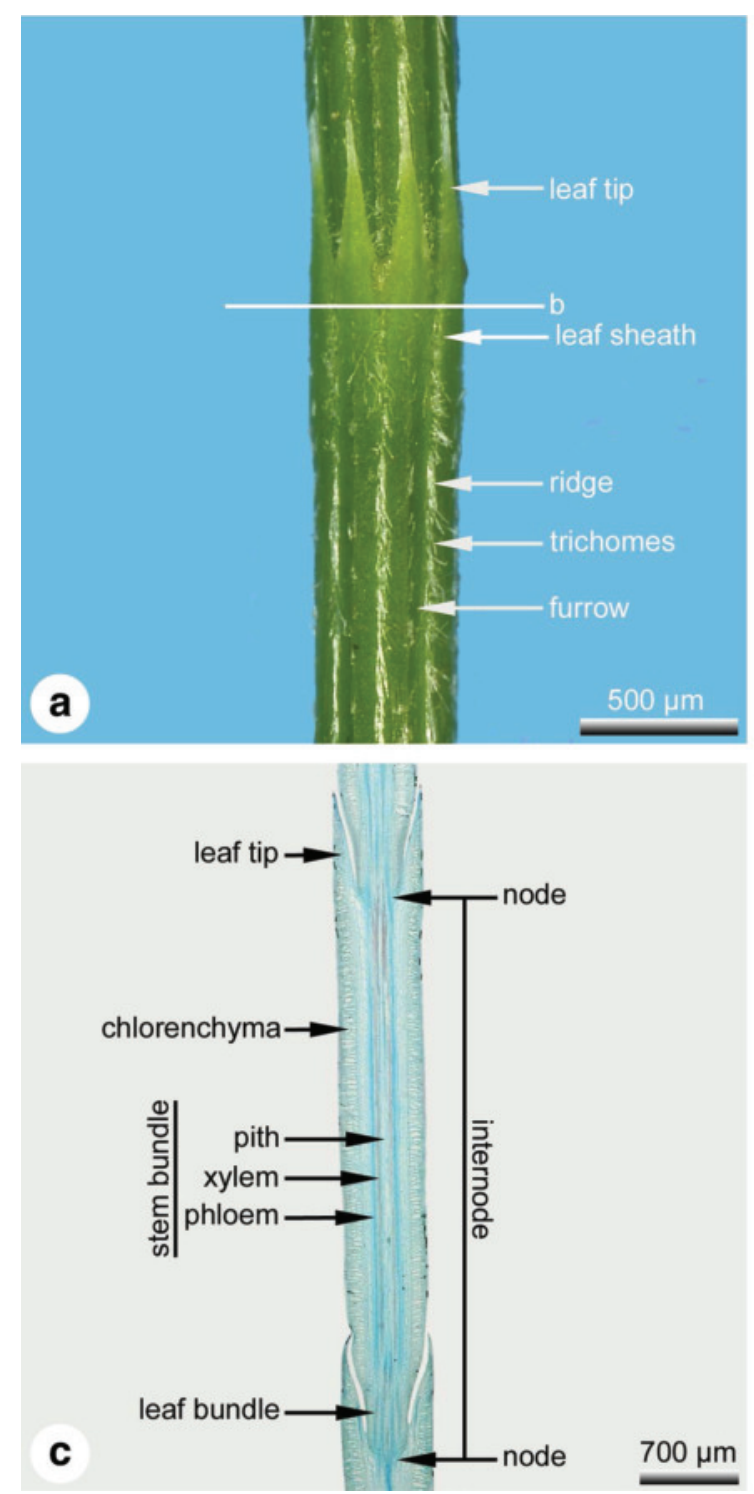

Fig. 2 Casuarina cunninghamiana, leaf development in different ontogenetic stages II: adult leaves; $\mathbf{a}$ in distal parts adult leaves are forming a leaf sheath surrounding the subsequent node; $\mathbf{b}$ cross section as marked in $\mathbf{a}$; $\mathbf{c}$ longitudinal section of a complete internode;

is supplied with one, unbranched, collateral vascular bundle strand. There is no distinct bundle sheath (Fig. 4d).

\section{Adult leaves}

6-8 leaves are inserted per node in the branchlets of adult individuals (Fig. 5a). They are 6-13-mm long and 0.2-0.4-mm wide (Fig. 5b). They are strongly fused to each other and to the cortical tissue of the complete internode (Figs. 5b-d, 6b-f). Only the hyaline leaf tips remain free (Fig. 5a). Later they become withered and brown. At the subsequent node, the leaves are still fused to each other but no longer to the shoot axis. They surround the node as a
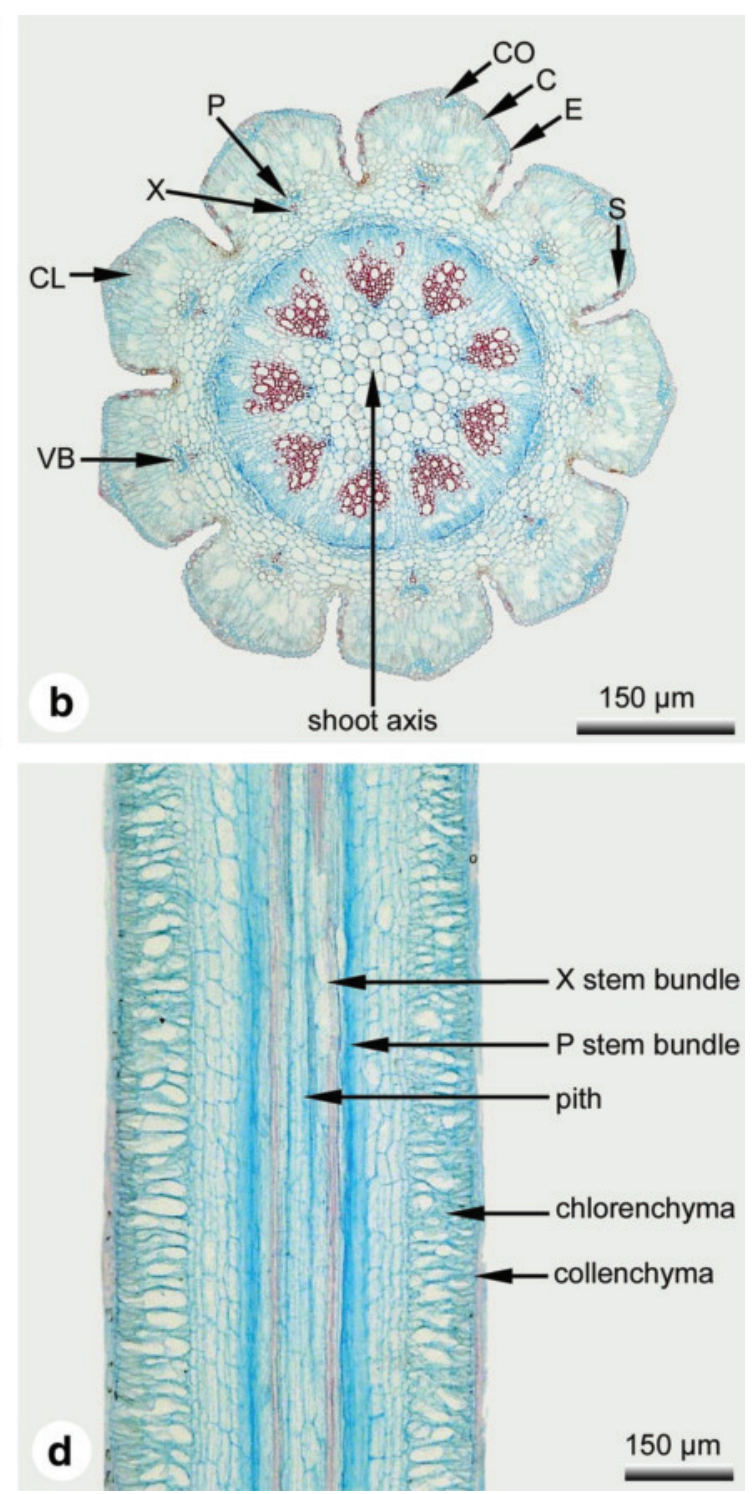

d detail of c, between the leaf- and shoot-tissue no sharp boundary layer is developed. $C$ cuticle, $C L$ chlorenchyma, $C O$ collenchyma, $E$ epidermis, $P$ phloem, $S$ stoma, $V B$ vascular bundle, $X$ xylem

closed leaf sheath (Fig. 6a). There is no sharp boundary layer between leaf- and shoot-tissue (Figs. 5c, d, 6b-f). The margins of two adjacent leaves form a nearly closed vertical furrow where strongly encrypted stomata are developed (Fig. 5a, b). In the light-exposed parts, stomata are absent. Below the epidermis a well-developed sclerenchyma occurs, consisting of two layers of strongly lignified cells. In the region of the midvein, the sclerenchyma consists of up to seven layers (Fig. 5b). In some leaves, the sclerenchyma is T-shaped and developed from shortly above the vascular bundle to directly below the epidermis. A palisade parenchyma-like chlorenchyma is developed below the sclerenchyma. Due to the T-shape of the sclerenchyma, the 

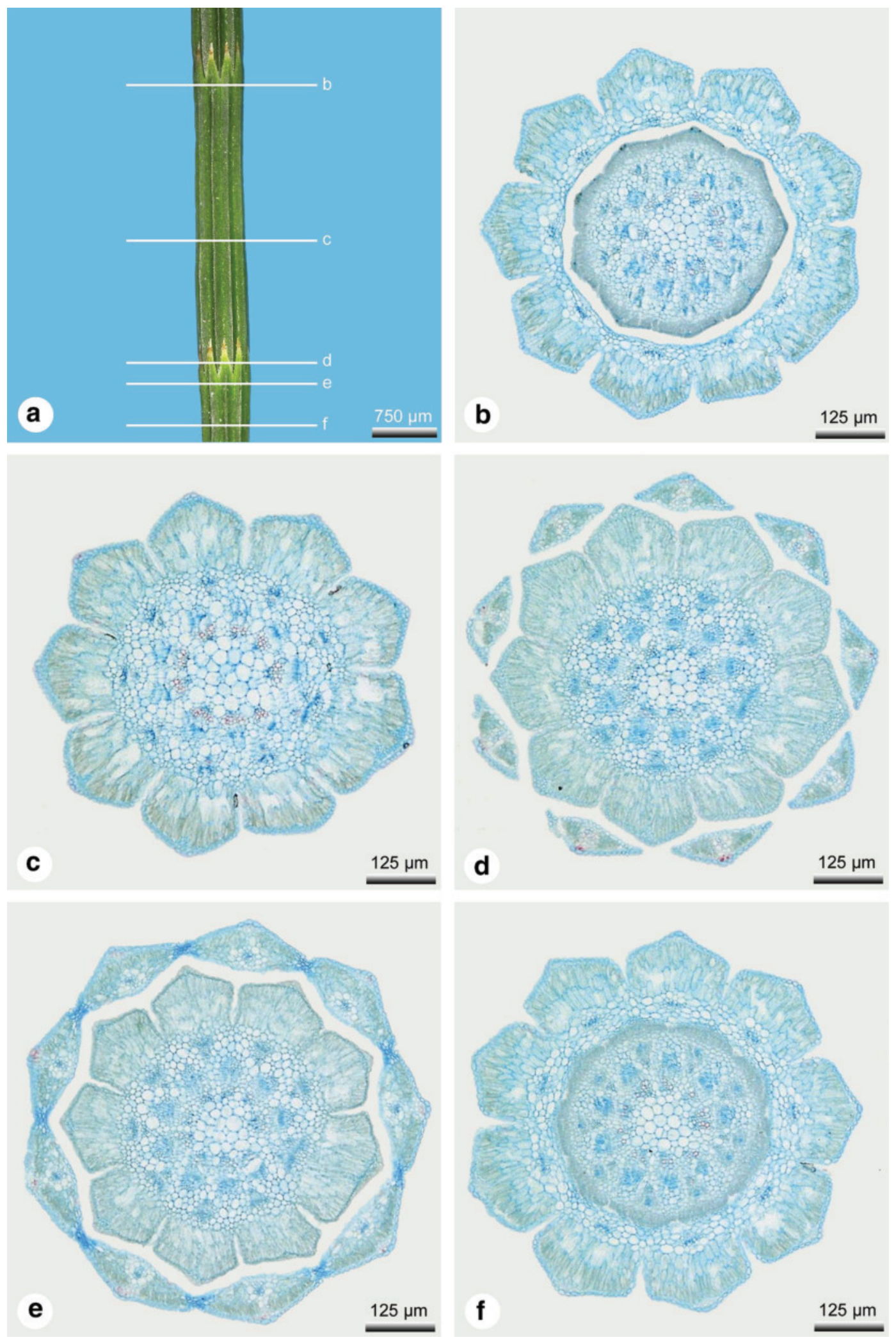

Fig. 3 Casuarina cunninghamiana, serial sections of an internode; a close up of one internode; $\mathbf{b}-\mathbf{f}$ cross-sections as marked in a 

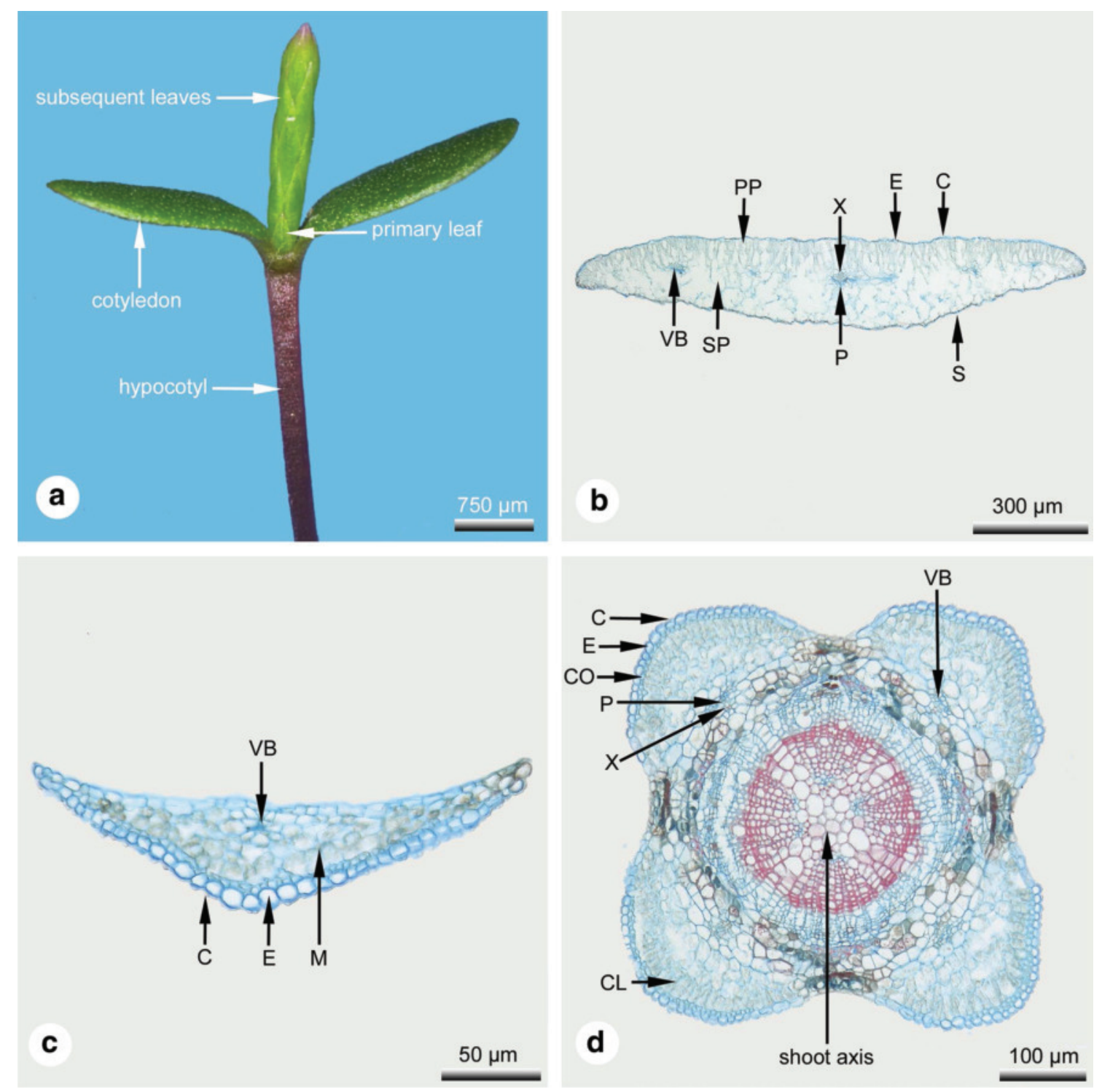

Fig. 4 Casuarina equisetifolia, leaf development in different ontogenetic stages I: juvenile leaves; a seedling; b cotyledon (cross section); c primary leaf (cross section); d young subsequent leaves at the

chlorenchyma is divided into two parts, one on either side of the ridge. Each leaf is supplied with a single collateral, unbranched vascular bundle strand. There is no distinct bundle sheath (Fig. 5b).

\section{Discussion}

\section{The morpho-anatomical shift from juvenile to adult foliage}

A major finding of the results is that the juvenile subsequent leaves and the adult leaves of both species are whorled, strongly reduced and fused to the shoot axis

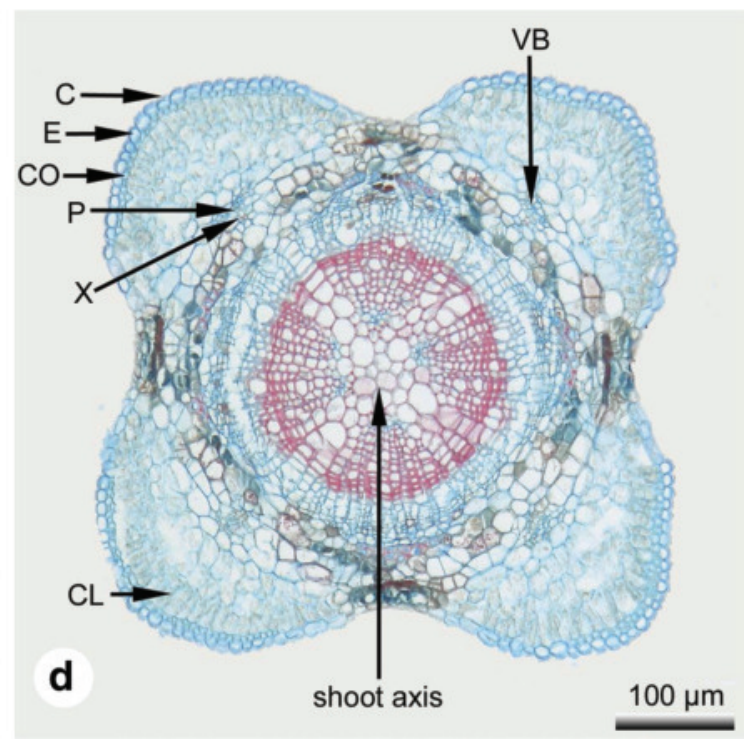

shoot axis (cross axis). $C$ cuticle, $C L$ chlorenchyma, $C O$ collenchyma, $E$ epidermis, $M$ mesophyll, $P P$ palisade parenchyma, $P$ phloem, $S$ stoma, $S P$ spongy parenchyma, $V B$ vascular bundle, $X$ xylem

except for the leaf tips; the shoot axis is surrounded completely by green palisade parenchyma-like leaf tissue which performs virtually all the of the photosynthesis. This is very different to the structure of superficially similar leafless or virtually leafless seed plants like Ephedra (Ephedraceae, Gymnospermae), Cytisus, Genista and Spartium (Fabaceae, Angiospermae) where photosynthesis is restricted to green chlorenchymatic stem tissues of the outer stem cortex (Thompson 1912; Voth 1934; Cutler 1939; Inamdar and Bhatt 1971; Freitag and Maier-Stolte 2003; Dörken 2014). A similar situation to that found in Casuarina is found in some gymnosperm species, e.g. Diselma, Chamaecyparis, Fokienia and Thuja (Cupressaceae), where the shoot axis is also completely surrounded by leaf 

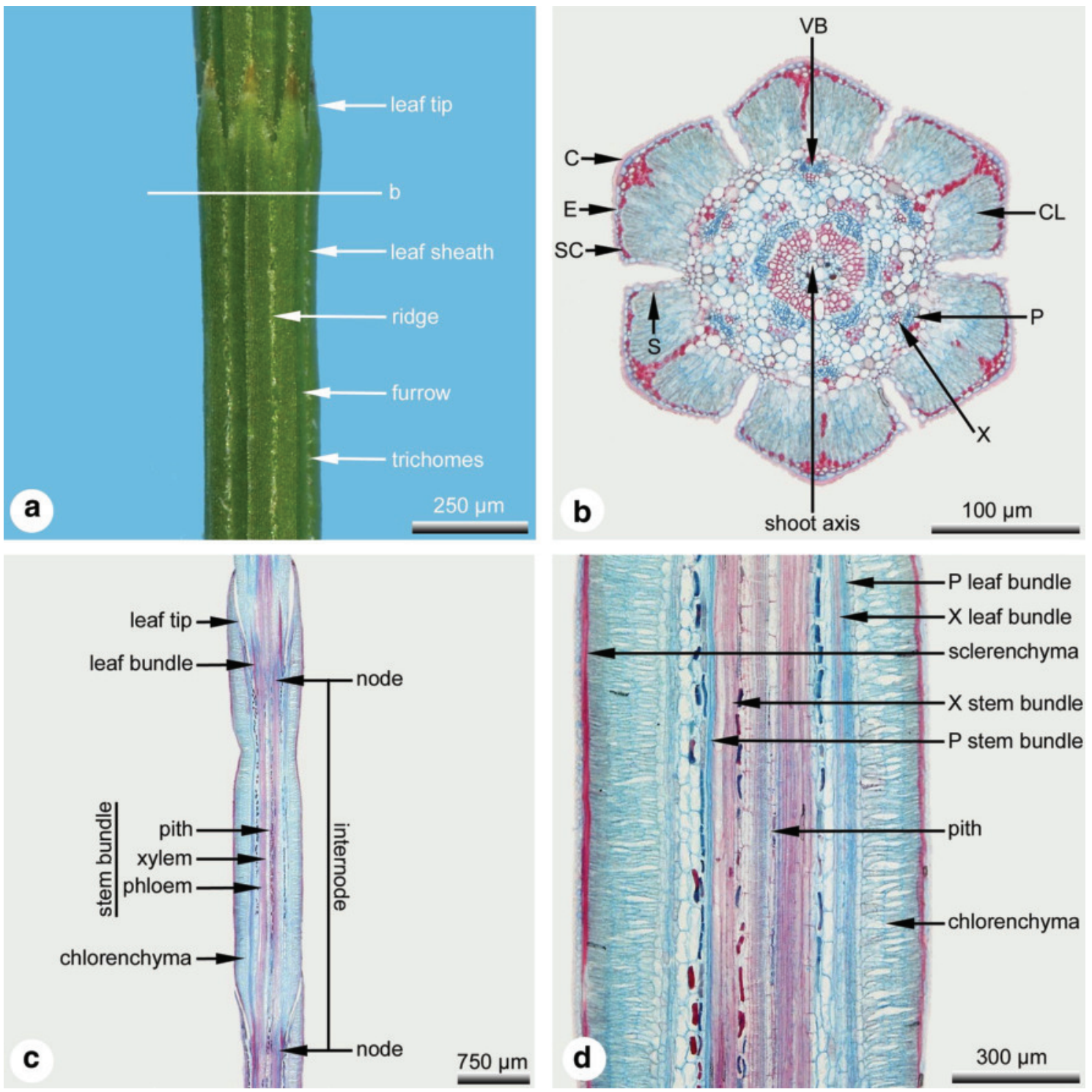

Fig. 5 Casuarina equisetifolia, leaf development in different ontogenetic stages II: adult leaves; $\mathbf{a}$ in distal parts adult leaves are forming a leaf sheath surrounding the subsequent node; $\mathbf{b}$ cross section as marked in $\mathbf{a} ; \mathbf{c}$ longitudinal section of a complete internode; $\mathbf{d}$ detail

tissue (e.g. Feustel 1921; Krüssmann 1983; Farjon 2005, 2010a, b; Tetzlaf 2005; Eckenwalder 2009; Dörken 2013), albeit with much shorter internodes than Casuarina where an extended toothed leaf sheath performs virtually all of the photosynthesis. To our knowledge, this Casuarina strategy for achieving reduced photosynthetic area has not been recorded before, except possibly in the case of Tamarix aphylla (L.) Karsten (see Fig. 8b of Gaskin 2003).

Our finding that Casuarina shoots are clothed by leaf tissue conflicts with the current literature, where Casuarina shoots are referred to as "cylindric cladodes" (e.g. Rao 1972; Zimpfer et al. 2004; Niinemets et al. 2005) and of $\mathbf{f}$, no sharp boundary layer between the leaf- and shoot-tissue is developed. $C$ cuticle, $C L$ chlorenchyma, $E$ epidermis, $P$ phloem, $S$ stoma, $S C$ sclerenchyma, $V B$ vascular bundle, $X$ xylem

"phylloclades" (Warrier et al. 2013). These terms refer to stem tissue not leaf tissue and so are inappropriate.

All subsequent juvenile leaves and adult leaves of both species have a well-developed collenchyma with strongly thickened cell walls directly below the epidermis except for the adult leaves of $C$. equisetifolia, where that tissue is replaced by a well-developed sclerenchyma with strongly thickened and lignified cell walls. While it appears that C. equisetifolia occurs in drier and generally more stressful habitats than $C$. cunninghamiana (see below), the exact reasons for the presence of sclerenchyma in $C$. equisetifolia are not yet known. 

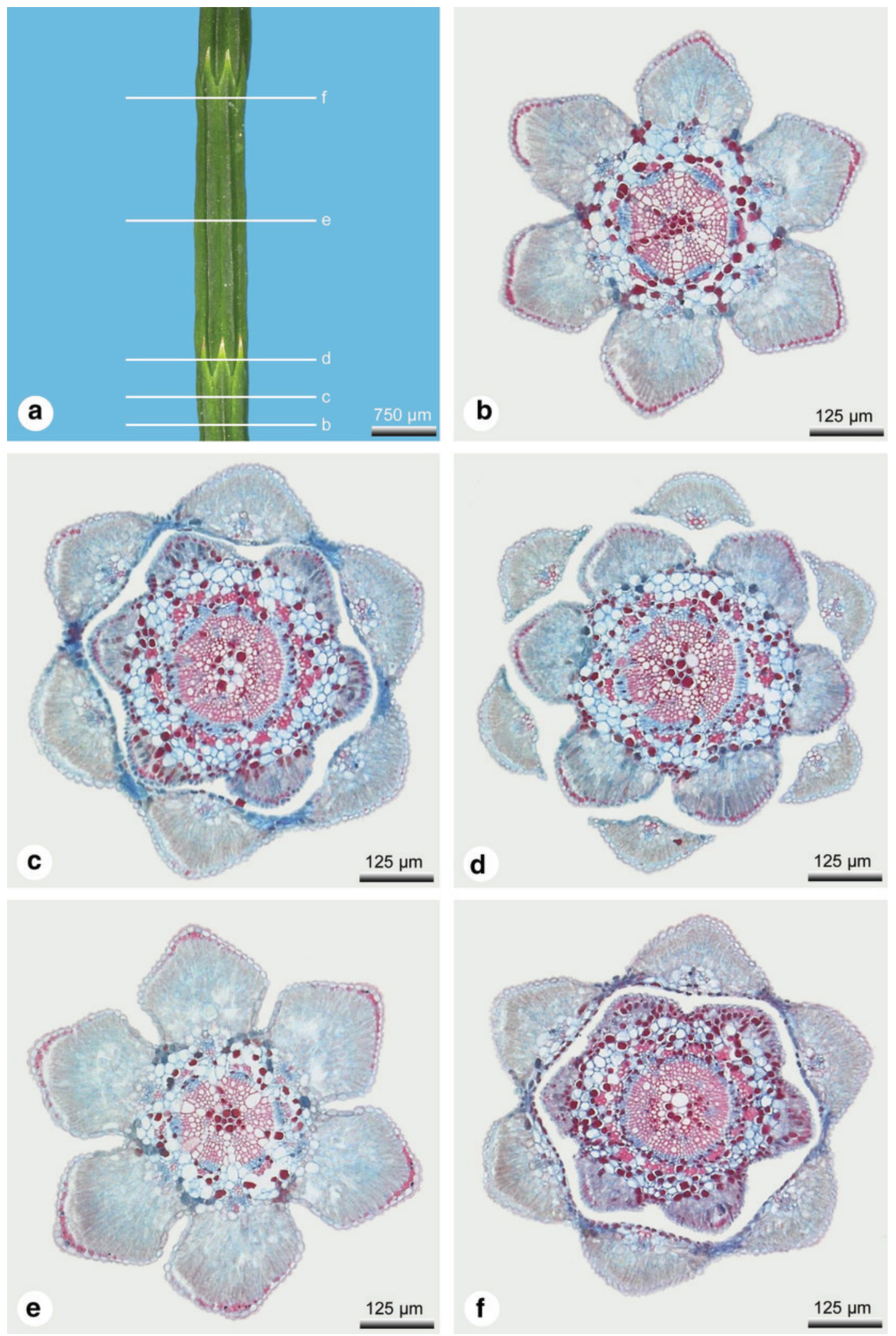

Fig. 6 Casuarina equisetifolia, serial sections of an internode; $\mathbf{a}$ close up of one internode; $\mathbf{b}-\mathbf{f}$ cross-sections as marked in $\mathbf{a}$ 
Among extant seed plants, it is not uncommon for the leaf morphology and anatomy of young seedlings to differ markedly from those in adults, as in Acacia (Pedley 1986) and Eucalyptus (Stebbins 1950). Such observations are often related to the "Rekapitulationstheorie" put forward by Ernst Häckel in 1866 that ontogeny recapitulates phylogeny, so that, e.g. in phyllodinous Acacia species the juvenile pinnate leaves represent the ancestral type of adult foliage (Pedley 1986). In the Casuarinaceae, Gymnostoma is clearly the most mesic of the present day genera and is very likely to include the ancestral types. This idea is supported by the fact that in molecular-based phylogenetic family trees, Gymnostoma is always placed as basal (Steane et al. 2003). Several significant similarities exist between young Casuarina seedlings and adult Gymnostoma plants, for example four leaves at a node, shallow furrows between the leaves and non-encrypted stomata that are not covered with trichomes. Thus, the Casuarina juvenile features may represent ancestral, scleromorphic Gymnostoma adult features which are then replaced by derived xeromorphic features in adult Casuarina.

\section{Correlation between leaf structure and environmental conditions}

The morpho-anatomical characters of Casuarina shoots lead to slow growth, which makes these species poor competitors for light compared to broad-leaved species. Thus, Casuarina is often found on sites showing unfavourable conditions for other trees like drought, skeletal, rocky soils or seasonally waterlogged flood plains, marsh margins, deep sand of beach foredunes that includes further stresses such as excessive drainage, soil alkalinity and exposure to wind and salt spray (Ladd 1988). Low fertility of the soils can also be involved (Ladd 1988; Reddell et al. 1997). Like the rest of the family, both $C$. equisetifolia and C. cunninghamiana have clustered/ proteoid roots and the nitrogen fixing actinomycete Frankia in root nodules, both being adaptations to infertile soils, especially to low levels of nitrogen and phosphorus (Torrey and Berg 1988; Reddell et al. 1986, 1997; Stevens 2015).

Both species are common in wet areas up to 1500mm mean annual rainfall. While $C$. cunninghamiana is a medium-sized to tall tree 20-30-m high (the largest Australian Casuarina), $C$. equisetifolia is a smallish tree 8-16-m high (Boland et al. 2006). Also, C. cunninghamiana, being riparian, receives supplementary moisture from flooding and often occur in sheltered areas transitional to rain forests (Ladd 1988). All of this suggests more stressful habitats for $C$. equisetifolia, the stresses including water deficit from excessive drainage on deep sands and wind exposure, as well as exposure to salt spray and alkaline coastal sands (Ladd 1988). All this might lead to the formation of the well-developed sclerenchyma in the adult leaves of C. equisetifolia.
Casuarina species, and the whole family of the Casuarinaceae, are widely regarded as a group of plants well adapted to xeric conditions (Rao 1972; Heywood 1978; Ladd 1988; Schütt et al. 2002). Most Casuarina species occur in regions with high temperatures and periodic water stress in combination with strong light and so are regarded as highly specialised xerophytes. This idea is supported by the fact that within Casuarina, stomata are nearly exclusively encrypted in deep, vertical, nearly closed furrows with a sharp functional boundary layer between the stomatal zone and the chlorenchyma where they are well protected against low humidity and high solar radiation and which may represent a selective advantage in dry climates (Heywood 1978; Steane et al. 2003).

However, in one genus of the Casuarinaceae, the stomata are not strongly encrypted. In Gymnostoma, the shoots are more or less quadrangular in cross section with four strongly reduced leaves per node. The four vertical furrows on the shoot are widely opened, and the stomata are non-encrypted and freely exposed to the environmental conditions (Torrey and Berg 1988; Wilson and Johnson 1989; Steane et al. 2003). Furthermore, the stomata of Gymnostoma differ from those of the more xeromorphic genera of the Casuarinaceae by a well developed internal opening into large intercellular chambers that can facilitate the gas exchange between the environment and the photosynthetic tissue (Torrey and Berg 1988), a feature lacking in Casuarina. By allowing for more furrows per internode, the 6-10 leaves per node in the species studied compared to four in Gymnostoma may represent a further xeromorphic development in addition to the stomatal one.

The first Casuarinaceae were possibly rainforest associated taxa occurring in wet climates (Ladd 1988). Thus, the oldest known Casuarinaceae fossils lack xeromorphic features, and stomata were developed in open furrows with few or no trichomes (Steane et al. 2003). From the upper Palaeocene of Australia, branchlets which developed four leaves per node are reported as Gymnostoma antiquum and are supposed to reflect the most primitive character states within the Casuarinaceae (Scriven and Hill 1995). Thus, fossil specimens of the Casuarinaceae clearly show that an increased number of leaves per node and also the encryption of stomata are derived features.

The southern Australian climate has significantly changed during the last 35 million years and shifted from ever-wet with mild temperatures to hot dry summers in combination with mild and wet winters. Throughout this period of continental drying, the vegetation has significantly changed as has the morphology of the Casuarinaceae (Hill and Brodribb 2001). Hill (1990) suggested the Casuarinaceae as a group of plants showing perfectly the consequences of a developing aridity in southern Australia during the Cainozoic. Gymnostoma is described as 
Table 1 Traits which may be related to scleromorphy (S) and xeromorphy (X) in Gymnostoma and two species of Casuarina

\begin{tabular}{|c|c|c|c|}
\hline \multirow[t]{2}{*}{ Trait } & \multicolumn{3}{|l|}{ Taxon } \\
\hline & Gymnostoma & C. cunninghamiana & C. equisetifolia \\
\hline $\begin{array}{l}\text { Leaves per node/furrows } \\
\text { per internode }\end{array}$ & $4(S)$ & $6-10(X)$ & $6-8(X)$ \\
\hline Nature of furrow & Open (S) & Nearly closed (X) & Nearly closed (X) \\
\hline Encryption of stomata & Non-encrypted (S) & Strongly encrypted (X) & Strongly encrypted (X) \\
\hline Trichomes in furrows & Few or none $(\mathrm{S})$ & Numerous (X) & Numerous (X) \\
\hline
\end{tabular}

Gymnostoma data from Torrey and Berg (1988) and Steane et al. (2003) the only Casuarinaceae taxon that could be identified as widespread and common in the uniformly wet climate of the Palaeogene. Later when the southern Australian climate started drying, Gymnostoma was no longer so competitive and was largely replaced by the genera Casuarina and Allocasuarina Hill (1990). Hill and Brodribb (2001) suggest that Gymnostoma is adapted to oligotrophic soils, having an evergreen habit, extensive root system and strongly reduced and highly fibrous leaves, thus being scleromorphic. However, those features are also found in Allocasuarina and Casuarina. Importantly, those genera also have the stomatal and other xeromorphic features, described above which are absent from Gymnostoma.

The scleromorphic condition in Gymnostoma (Table 1) is the primitive state in the Casuarinaceae. Thus, it follows that more than four leaves per node as developed in Casuarina and Allocasuarina are a derived feature. The increasing number of leaves per node leads consequently to a strong reduction of the space between the leaves and an increased number of deep and nearly closed furrows in the shoot. This, with the stomatal characters above, are a probable selective advantage in dry climates. It seems likely that the primitive scleromorphic features among the first Casuarinaceae were excellent preconditions to develop resistance against the drying of the climate. The evergreen habit with strongly reduced leaves that are nearly completely fused to the shoot and also the large amount of collenchyma/sclerenchyma within the leaves may represent primitive scleromorphic features which evolved as a response to low soil fertility, that secondarily prevent wilting of branchlets in times of drought and thus may be an important feature allowing Casuarina to inhabit extremely xeric sites. The extreme drought resistance of Casuarina stricta (now Allocasuarina verticillata (Lam.) L.A.S. Johnson) was shown in the field observations of Ashton et al. (1975).

\section{Concluding discussion}

In this paper on the Casuarinaceae, using detailed morphoanatomical work and palaeobotanical and ecological data, we have been able to document the shift from scleromorphic to xeromorphic features with changing climatic conditions. In addition, for the first time, we have been able to show that the Casuarina branchlet is not made up of cladodes but of extended leaf sheaths. These may be a novel strategy for achieving reduced photosynthetic area.

Author contribution statement VD and RP constructed and designed the experiments. RP located the seeds. VD performed the experiments and made the figures. Both authors analyzed the data and wrote the paper.

Acknowledgements We are grateful to Mr. Otmar Ficht and Mrs. Anne Kern (Botanic Garden, University of Konstanz, Germany) for producing the seedlings. Furthermore, we thank the Botanic Garden of the Ruhr-University of Bochum (Germany) for generously providing research material and Dr. Michael Laumann and Mrs. Lauretta Nejedli (Electron Microscopy Center, Department of Biology, University of Konstanz, Germany) for technical support (paraffin technique). Finally, we thank Dr. Philip Ladd (Murdoch University, Australia), Dr. Mike Bayly (University of Melbourne, Australia) and Dr. Ian Staff (LaTrobe University, Australia) for helpful advice.

\section{Compliance with ethical standards}

Conflict of interest The authors declare that they have no conflict of interest.

\section{References}

Ashton DH, Bond H, Morris GC (1975) Drought damage on Mount Towrong, Victoria. Proc Linn Soc New South Wales 100:44-69

Beadle NCW (1966) Soil phosphate and its role in molding segments of the Australian flora and vegetation with special reference to xeromorphy and sclerophylly. Ecology 47:992-1007

Blum A (1996) Crop responses to drought and the interpretation of adaptation. Plant Growth Regul 20:135-148

Blum A, Arkin GF (1984) Sorghum root growth and water use as affected by water supply and growth duration. Field Crop Res 9:131-142

Boland DJ, Brooker MIH, Chippendale GM, Hall N, Hyland BPM, Johnston RD, Kleinig DA, McDonald, MW, Turner JD (2006) Forest trees of Australia, 5th edn. CSIRO, Collingwood 
Bosabalidis AM, Kofidis G (2002) Comparative effects of drought stress on leaf anatomy of two olive cultivars. Plant Sci 163:375-379

Cutler HC (1939) Monograph of the North American species of the genus Ephedra. Ann Mo Bot Gard 26:373-428

Dörken VM (2013) Leaf dimorphism in Thuja plicata and Platycladus orientalis (thujoid Cupressaceae s. str., Coniferales): the changes in morphology and anatomy from juvenile needle leaves to mature scale leaves. Plant Syst Evol 299:1991-2001

Dörken VM (2014) Leaf-morphology and leaf-anatomy in Ephedra altissima Desf. (Ephedraceae, Gnetales) and their evolutionary relevance. Feddes Repert 123:243-255

Dörken VM, Jagel A (2014) Pinus sylvestris-Wald-Kiefer (Pinaceae), Baum des Jahres 2007. Jahrb Bochumer Bot Ver 5:246-254

Dörken VM, Parsons R (2016) Morpho-anatomical studies on the change in the foliage of two imbricate-leaved New Zealand podocarps: Dacrycarpus dacrydioides and Dacrydium cupressinum. Plant Syst Evol 302:41-54

Düll R, Kutzelnigg H (2011) Taschenlexikon der Pflanzen Deutschlands und angrenzender Länder, 7th edn. Quelle \& Meyer, Wiebelsheim

Eckenwalder JE (2009) Conifers of the World. Timber Press, Portland

Farjon A (2005) A monograph of Cupressaceae and Sciadopitys. Royal Botanic Gardens, Kew

Farjon A (2010a) A handbook of the world's conifers, vol I. Brill, Leiden

Farjon A (2010b) A handbook of the world's conifers, vol II. Brill, Leiden

Feustel H (1921) Anatomie und Biologie der Gymnospermenblätter. Beih Bot Centralbl 38:177-253

Foster AS, Gifford EM (1974) Comparative morphology of vascular plants. 2nd edn. Freeman, San Francisco

Freitag H, Maier-Stolte M (2003) The genus Ephedra in NE tropical Africa. Kew Bull 58:415-426

Gaskin JF (2003) Tamaricaceae. In: Kubitzki K, Bayer C (eds) The families and genera of vascular plants, vol 5. Springer, Berlin, pp 336-338

Gerlach, D (1984) Botanische Mikrotomtechnik, eine Einführung. 2nd edn. Thieme, Stuttgart

Heywood VH (1978) Flowering plants of the world. Oxford University Press, Oxford

Hill RS (1990) Evolution of the modern high latitude southern hemisphere flora. Evidence from the Australian macrofossil record. In: Douglas JG, Christophel DC (eds) Proceedings 3rd IOP conference, Melbourne 1988. A-Z Publishers, Melbourne, pp 31-42

Hill RS (1998) Fossil evidence for the onset of xeromorphy and scleromorphy in Australian Proteaceae. Aust Syst Bot 11:391-400

Hill RS, Brodribb TJ (2001) Macrofossil evidence for the onset of xeromorphy in Australian Casuarinaceae and tribe Banksieae (Proteaceae). J Mediterr Ecol 2:127-136

Hill RS, Merrifield HE (1993) An early Tertiary macroflora from West Dale, southwestern Australia. Alcheringa 17:285-326

Inamdar JA, Bhatt DC (1971) Epidermal structure and ontogeny of stomata in vegetative and reproductive organs of Ephedra and Gnetum. Ann Bot (Oxford) 36:1041-1046

Korner C (2003) Alpine plant life, 2nd edn. Springer, Berlin

Krüssmann G (1976) Handbuch der Laubgehölze, vol. 1, 2nd edn. Parey, Berlin

Krüssmann G (1977) Handbuch der Laubgehölze, vol 2, 2nd edn. Parey, Berlin

Krüssmann G (1978) Handbuch der Laubgehölze, vol. 3, 2nd edn. Parey, Berlin

Krüssmann G (1983) Handbuch der Nadelgehölze, 2nd edn. Parey, Berlin
Kubitzki K (2004) The families and genera of vascular plants, vol 6. Flowering plants, dicotyledons: Celastrales, Oxalidales, Rosales, Cornales, Ericales. Springer, Berlin

Kubitzki K, Rohwer JG, Bittrich V (1993) The families and genera of vascular plants, vol 2. Flowering plants, dicotyledons: Magnoliid, Hamamelid and Caryophylloid families. Springer, Berlin

Ladd PG (1988) The status of Casuarinaceae in Australian Forests. In: Frawley KJ, Semple NM (eds) Australia's ever changing forests. Proceedings of the first national conference on Australian forest history, pp 63-85

Loveless AR (1961) A nutritional interpretation of sclerophylly based on differences in the chemical composition of sclerophyllous and mesophytic leaves. Ann Bot (Oxford) 25:168-184

Loveless AR (1962) Further evidence to support a nutritional interpretation of sclerophylly. Ann Bot (Oxford) 26:551-561

Niinemets Ü, Lukjanova A, Sparrow AD, Turnbull MH (2005) Light acclimation of cladode photosynthetic potentials in Casuarina glauca: trade-offs between physiological and structural investments. Funct Plant Biol 32:571-582

Parsons RF (2010) Whipcord plants: a comparison of south-eastern Australia with New Zealand. Cunninghamia 11:277-281

Pedley L (1986) Derivation and dispersal of Acacia (Leguminosae), with particular reference to Australia and the recognition of Senegalia and Racosperma. Bot J Linn Soc 92:219-254

Rao AN (1972) Anatomical studies on succulent cladodes in Casuarina equisetifolia Linn. Proc Indian Acad Sci B 76:262-270

Reddel P, Yun Y, Shipton WA (1997) Cluster roots and mycorrhizae in Casuarina cunninghamiana: their occurrence and formation in relation to phosphorus supply. Aust J Bot 45:41-51

Reddell P, Bowen GD, Robson AD (1986) Nodulation of Casuarinaceae in relation to host species and soil properties. Aust J Bot 34:435-444

Rehder A (1967) Manual of cultivated trees and shrubs, 2nd edn. The Macmillan Company, New York

Salleo S, Nardini A (2000) Sclerophylly: evolutionary advantage or mere epiphenomenon. Plant Biosyst 134(3):247-259

Schütt P, Schuck HJ, Stimm B (2002) Lexikon der Baum- und Straucharten. Nikol, Hamburg

Scriven LJ, Hill RS (1995) Macrofossil Casuarinaceae, their identification and the oldest macrofossil record, Gymnostoma antiquum sp. nov., from the Late Palaeocene of New South Wales, Australia. Aust Syst Bot 8:1035-1053

Seddon G (1974) Xerophytes, xeromorphs and sclerophylls: the history of some concepts in ecology. Biol J Linn Soc 6:65-87

Seidling W, Ziche D, Beck W (2012) Climate responses and interrelations of stem increment and crown transparency in Norway Spruce, Scots Pine and Common Beech. Forest Ecol Manag 284:196-204

Steane DA, Wilson KL, Hill RS (2003) Using matK sequence data to unravel the phylogeny of Casuarinaceae. Mol Phylogenet Evol 28:47-59

Stebbins GL (1950) Variation and evolution in plants. Columbia University Press, New York

Stevens PF (2015) Angiosperm Phylogeny Website, Version 13. http://www.mobot.org/MOBOT/research/-APweb/ (04 Oct 2015)

Taylor TN, Taylor EL, Krings M (2009) Palaeobotany: the biology and evolution of fossil plants. Academic Press, Burlington

Tetzlaf M (2005) Die Anatomie des Gymnospermenblattes unter funktionellen und evolutiven Gesichtspunkten. Diploma. RuhrUniversity, Bochum

Thoday D (1931) The significance of reduction in the size of leaves. J Ecol 19(2):297-303

Thompson WP (1912) The anatomy and relationships of Gnetales. I. The genus Ephedra. Ann Bot (Oxford) 27:1077-1104 
Torrey JG, Berg RH (1988) Some morphological features for generic characterization among the Casuarinaceae. Am J Bot 75:864-874

Voth PD (1934) A study of the vegetative phases of Ephedra. Bot Gaz 96:298-313

Warrier KCS, Suganthi A, Singh BG (2013) A new record of abnormal phylloclad modification in Casuarina equisetifolia. Int $\mathrm{J}$ Agric Sci Res 2:8-11

Wilson KL, Johnson LAS (1989) Casuarinaceae. In: George AS (ed) Flora of Australia, vol 3. Hamamelidales to Casuarinales. Australian Government Publishing Service, Canberra, pp 100-175
Zamaloa MC, Gandolfo MA, Gonzales CC, Romero EJ, Cuneo NR, Wilf P (2006) Casuarinaceae from the Eocene of Patagonia, Argentina. Int J Plant Sci 167:1279-1289

Zimpfer JF, Igual JM, McCarty B, Smyth C, Dawson JO (2004) Casuarina cunninghamia tissue extracts stimulate the growth of Frankia and differentially alter the growth of other soil microorganisms. J Chem Ecol 30:439-452 